\title{
Nude Mouse Shared Resource
}

National Cancer Institute

\section{Source}

National Cancer Institute. Nude Mouse Shared Resource. NCI Thesaurus. Code C39479.

The Nude Mouse Shared Resource provides immunodeficient mice to Cancer Center investigators, appropriate housing and maintenance for these animals, as well as technical expertise and barrier working laboratories for in vivo experiments. 